\title{
Filipino Sign Language Skills and Deaf Culture Awareness in Hospitality Industry Employability
}

\author{
Ma. Aurora C. Niebla \\ Hospitality Management Department, College of Home Economics, Western Mindanao State University, \\ Philippines
}

\begin{abstract}
Many Deaf Filipinos remain unemployed despite the increased attention level from the hospitality industry. The study aimed to examine the levels of awareness on Deaf culture and FSL skills within the hospitality industry of Zamboanga City to foster sustainable employment - including quality service; it used a descriptive research design employing qualitative and quantitative approaches. The sample group was purposively selected from 4 hotels and 8 restaurants - duly accredited by the Department of Tourism Region 9 as of December 31, 2018. The study revealed that Zamboanga City hospitality industry stakeholders were aware 1) of Deaf culture; that 2) Deaf individuals can visually communicate through reading, writing, gestures, or FSL; 3) they can visually communicate with Deaf individuals regardless of their FSL knowledge or skills; also, 4) there was no significant difference in the respondents' levels of awareness on Deaf culture and FSL skills in the area; 5) an intervention program is needed to increase Deaf Zamboangeños' hospitality employability. The study concluded that Zamboangeño hospitality industry stakeholders 1) were aware of Deaf culture and FSL skills despite linguistic differences; 2 ) can visually communicate with Deaf individuals despite having little to no FSL skills nor Deaf culture knowledge; also, 3) the communication models affect Deaf individuals' hospitality employability and capability; and, 4) Deaf culture awareness and FSL skills through interactive interaction among Deaf and hearing individuals, within hospitality business operations, are crucial in emerging communication patterns.
\end{abstract}

Keywords: Deaf Culture Awareness;, Deaf Employment;, Filipino Sign Language Skills; Hospitality Industry; Inclusive Environment

This is an open access article under the CC-BY-NC license.

\section{INTRODUCTION}

There was an increased level of attention among hospitality firms in the world on the importance of giving employment and training to people with hearing impairment or the Deaf. Campbell (1996), as cited by Zahari, M. et al. (2010), reported that there are thousands of disabled graduates with hearing impairment who do wide ranges of work, including high-pressured jobs requiring high skill level in the United States of America and these groups of people are equally productive - remain with the employer for a longer period and tend to have better performance Corresponding author Ma. Aurora C. Niebla, ma.niebla@wmsu.edu.ph DOI: https://doi.org/10.31098/tsdr.v2i2.50 
than average employees. Furthermore, Malaysia has introduced continuing skills-based programs for young hearing-impaired students with the intention to equip them for industry careers including the hospitality industry. However, despite the growing number of disability acts enacted in many countries, there were still a large number of graduates with disabilities excluded from employment. They were still being taken for granted by society. The voice of the deaf individuals was not often desirably heard. More often, preferences for employment go to the hearing individuals. The hospitality industry was not excused from this practice. Amir, Strauser and Chan (2009), as cited by Burke, J., Bezyak, J., Fraser, R., Pete, J., Ditchman, N., et al. (2013, July), stated that there were many positive attributes and reasons for hiring PWDs. However, negative attitudes of co-workers or supervisors and the lack of qualified PWDs were frequently cited as the major barrier in hiring and retaining people with disabilities. The same sad plight of Deaf people happens in the hospitality industry of the Philippines. Employability of Persons with Disabilities (PWD) is still in scarcity despite the Magna Carta for PWD under Republic Act 7277 and Republic Act 10524. Hence, the purpose of the study was to examine the levels of awareness of Deaf culture and FSL skills of hearing hospitality stakeholders. Likewise, it gained insights as to the Deaf individuals' dealing and communicating with the hearing individuals within the hospitality industry of Zamboanga city, leading to - fostering sustainable employment. The findings of the study will be beneficial to the Department of Tourism, Deaf people, Hospitality Industry, Academe, and Local Government Units.

"Deaf people up to now are still stigmatized as senseless, uneducable, and people incapable of reason or of ever becoming productive members of a society" according to Christiansen \& Barnett, 1995; Ladd, 2003 as cited by McCaskill, A., \& O'Brien, C. (2016). For such reason, Deaf individuals feel humiliated and outcast. "The manifestations of social oppression as related to Deaf and hard of hearing individuals, their sense of identity, and the negative influence of normalcy are important to understanding the stigma of being Deaf in a hearing world" according to Horejes, 2012; Leigh, 2009 as cited by McCaskill, A., \& O'Brien, C. (2016). Past stigmatizing, communication failures, cultural and language barriers, and social isolation might be some of the reasons why Deaf and hard of hearing people are reluctant to interact with the hearing world, according to Lane, 1992 as cited by McCaskill, A., \& O'Brien, C. (2016). On the issue of the communication process, in an interview with a SPED interpreter in Zamboanga City, after the proclamation of the Filipino Sign Language (FSL) as the national sign language of the Filipino Deaf and the official sign language of the Philippine government in all transactions involving the Deaf, signed into law by President Rodrigo R. Duterte on October 30, 2018, as Republic Act No. 11106, otherwise known as the "Filipino Sign Language Act", stressed that the schools in Zamboanga City offering SPED classes used the Signing Exact English (SEE) - a sign system that matches the sign language with the English language because it was molded from it. Deaf students learned standard idiomatic English as any hearing children learning the English language, according to Modern Signs Press (C) 1973-2019). She also said that FSL is similar to American Sign Language (ASL) - a language in and of itself with its own grammar, syntax and idioms according to Modern Signs Press (C 1973-2019). In a YouTube video of ASL THAT (2016, Oct 19), ASL was shown to be a much faster way of communication than SEE which required the signer to sign all the words as it should be in English. 


\section{Statement of the Problem}

The study aimed to examine the levels of awareness on Deaf culture and FSL skills of hearing hospitality stakeholders. Likewise, it gained insights as to the Deaf individuals' dealing and communicating with the hearing individuals within the hospitality industry of Zamboanga city leading to - fostering sustainable employment. The study specifically sought to answer the following questions: 1) What levels of awareness did hearing hospitality industry stakeholders possess on Deaf culture? 2) What levels of awareness did hearing hospitality industry stakeholders possess on Filipino Sign Language? 3) To what category of communication did the hospitality stakeholders belong? 3.1) border crossers, 3.2) borderlands, 3.3) border crossing. 4) Was there a significant difference between the respondents' levels of awareness on Deaf culture and FSL skills in the hospitality industry of Zamboanga City? 5) What output is to be developed as an intervention program to the study?

\section{Significance of the Study}

The findings of the study will be beneficial to the following: Department of Tourism - They will serve as a basis in assisting the hospitality industry and the Deaf people to find a common ground that will be beneficial to both groups. Deaf people - They will be understood better, so they will be provided with appropriate skills and competencies to be able to join the hospitality industry in the near future. Hospitality Industry - They will be guided on how to manage Deaf people in their workforce and maximize their contribution to its growth. Academe - They will have deep insight as to the kind of training program they should provide to Deaf people so they can increase their employment capacity in the hotel industry. Local Government Units - They will be properly guided as to the kind of assistance they could extend to their constituents who are Deaf people.

\section{LITERATURE REVIEW}

The hospitality industry in Zamboanga City should learn from the benefits of a diverse workforce. Palmer, D. (2019, Apr 19) said that diversifying into the disabled community will attract the best people, foster collaboration, represent the workforce community, adopt inclusion as a practice, and see greater returns. She stressed further that a robust workforce should include people from all walks of life - including people with disabilities. Neglecting this social responsibility will negatively impact businesses as they move into a more customer and candidate-driven environment. There is proof of development to that.

In fact, a related article by O'Grady (2018, Nov 01) revealed that Starbucks opened its first American Sign Language Starbucks (ASL) in the United States, with all employees being fluent in ASL to engage the Deaf and hearing-impaired community in Washington, DC, and follows in the footsteps of a Starbucks in Malaysia that opened a similar Starbucks "Signing Store" in 2016. In another article, Feigenbaum, P. (2017, Oct 16) reported that the Spanish hotel chain known as Room Mate Hotels is offering real-time sign-language interpretation services for deaf and hard of hearing guests. Similarly, Chuang, P. M. (2012, Mar 26) wrote that a 26-year veteran hotelier in Singapore, Ms Fauziah, trains handicapped individuals in housekeeping duties and prepares them for future careers in Holiday Inn Orchard and in the hospitality industry. Furthermore, the chief executive of Kentucky Fried Chicken Management and Pizza Hut Singapore urge other employers to offer jobs to the handicapped and readily shares his company's experience of employing them. 
Moreover, Kazmin, A. (2018, Mar 16) stated in his article that Lemon Tree, India's biggest mid-market hotel chain, actively seeks out disabled people to employ at its 44 sites across the country employs 550 disabled workers account for 12 per cent of the chain's 4,600-strong workforce - mostly hearing-and speech-impaired but also wheelchair users and amputees. Hospitality News Philippines (2013, Feb 25) published an article that revealed Holiday Inn Makati is one of the hotels in the Philippines that employs PWDs and has finally hired its first Deaf employee. Similarly, its neighbor Makati Shangri-la hotel is also known to employ PWDs and even involve them in internships. InfoBoholPhilippines (2018, Aug 31) revealed in its article that Dao Diamond Hotel in Tagbilaran City, Bohol is a Deaf friendly hotel that offer Deaf friendly tours wherein all of their tour operators and employees are required to know sign language.

Himor, J.P. (2018, Oct 12) wrote that persons with disabilities (PWDs) are often disadvantaged when it comes to getting hired, but due to constant call for equality in the playing field, more and more establishments are hiring PWDs, who despite their disabilities are hardworking people and often turning out to be great employees, proving how they can become strong assets to companies. Diversity in the hospitality industry will attract the best people, foster collaboration, represent the workforce community, adopt inclusion as a practice, and see greater returns. A robust workforce should include people with disabilities. Neglecting this social responsibility will negatively impact businesses as they move into a more customer and candidatedriven environment. The hospitality industry can start by understanding the deaf culture and the sign language of deaf people. In understanding the deaf culture, the hospitality industry can improve the practices with deaf people and maximize their contribution to the success of the industry. The culture of the Deaf and people with no hearing impediment can be bridged through communication through verbal and non-verbal, oral and written, formal and intentional and unintentional. The sign language of the Deaf people uses signs made with the hands, facial expressions, and body postures, but no sounds.

\section{Theoretical Framework}

The theoretical framework was anchored on the communicative models by Kreher, Y.W. (2013) that covered: border crossers, borderlands, and border crossing. Hearing border crossers are referred to as any hearing individual in a hospitality industry setting using his or her psychosocio operational linguistic patterns such as linguistic utterances, negotiation, interaction, and acceptance - in communicating with Deaf individuals on a casual level. On the other hand, borderlands were referred to as hearing border crossers who communicate with Deaf individuals in a casual and incidental manner in a hospitality industry setting. Similarly, border-crossing individuals were hearing border crossers who intentionally crossed virtual borders to communicate with Deaf individuals with their own psycho-socio operational linguistic patterns as well in a specific hospitality industry setting. These three models were used to test whether such models would be factors to the acceptance of prioritizing the Deaf individuals' employability in relation to their interaction with the hearing - specifically in hospitality business operations. Such framework was appropriate to the study because it related to the natural and factual reality of how people behave in society - most especially that all human beings were border crossers in a borderland who behaved in the way they did in a situation they were able comfortably to express, relate, deny, accept, and become influential border-crossing individuals, perhaps in the end or 
either way. That meant one gets into the world of others or others get into one's world through a natural communication process. Such a phenomenon could be called communication culture among Deaf and hearing individuals. In the process, Deaf culture was defined according to the following common observable behaviors of deaf individuals: belief system (norms and traditions), language, thought and meaning, attitude and actions. On the other hand, FSL skills were attributed to the following: lip reading and visual interpretation (facial expression, written, printed or projected symbols), psychomotor movements (gestures), and rhythmic patterns.

\section{Conceptual Framework}

Based on Kreher, Y.W. (2013), Figure 1 shows the conceptual framework of the study, which was focused on the stakeholders of the hospitality industry relative to the perceived degree of awareness on Deaf culture and its psycho-socio linguistics and interpersonal skills - that may appear in sign language skills in the hospitality operations.

The framework of the study was anchored on the subjects such as hearing and Deaf individuals who encountered and communicated in a natural setting - the starting point of relatedness and relationship as a result of their encounters. In the process, the levels of awareness of hearing hospitality industry stakeholders, particularly the workforce, job seekers, customers/ guests, and advocates of Deaf employment in the hospitality industry towards their understanding and interpretation of Deaf culture and FSL skills were explored in relation to fostering Deaf employment and quality services as the core problem of the study.

In addition, the communicative models of Kreher, Y.W. (2013), such as border crossers, borderlands, and border crossing, were used to determine their relationship with the communication processes between hearing and Deaf individuals that could possibly influence or affect the hospitality business operations of establishments such as hotels and restaurants in Zamboanga city. Likewise, the impact of the study was determined by the revelations from the focused group discussions through qualitative and quantitative methods.

Moreover, it pointed to the reality characterized by process-focused, detailed descriptions, inductive data analysis and concern with respondents' perspectives. Bogdan \& Biklen (2007) as cited in Kreher, Y.W. (2013). 


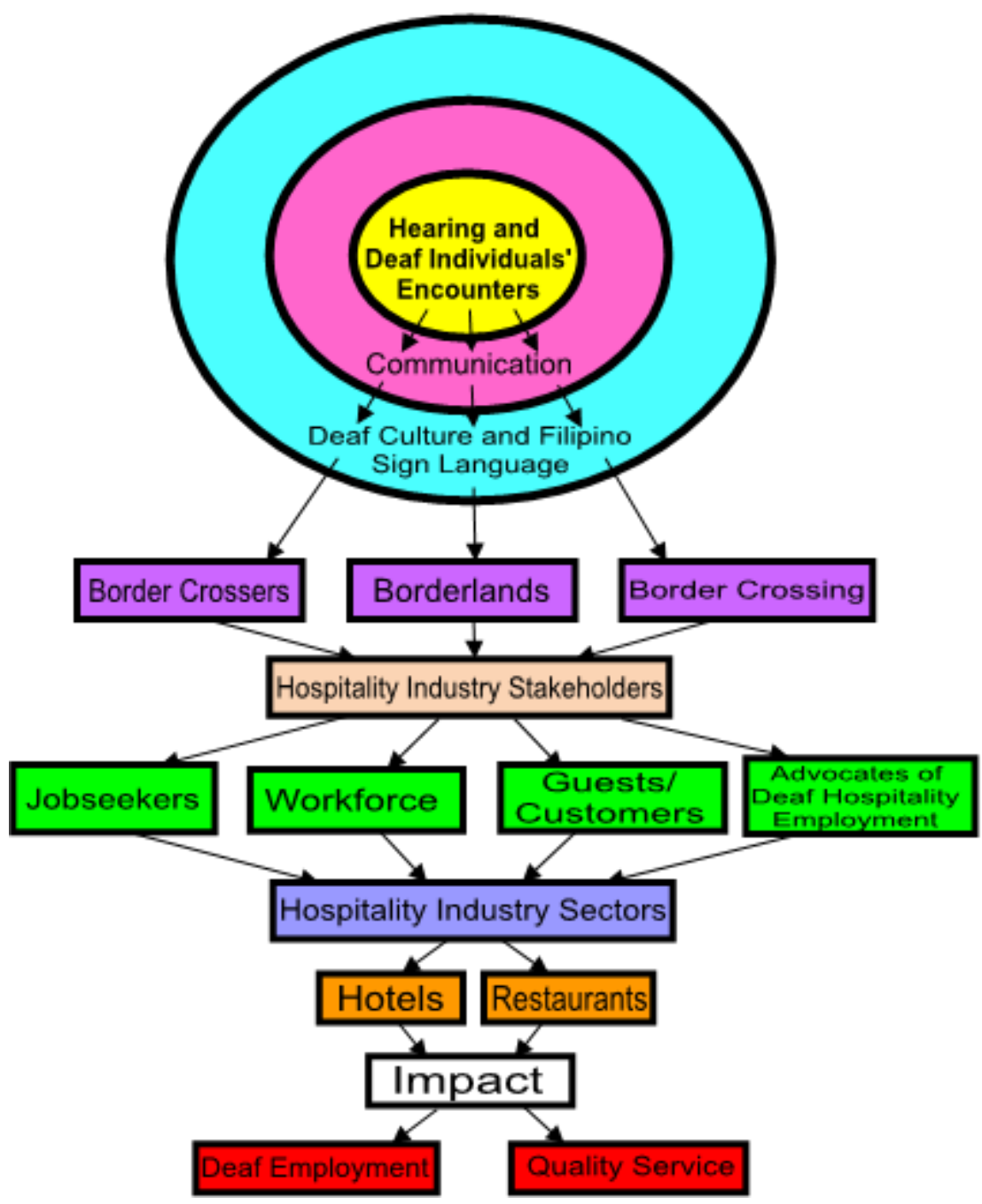

Figure 1. Schematic Diagram of the Conceptual Framework of the Study

Legend: $\square$ - The meeting of hearing and Deaf individuals, as subjects of the study, in a natural setting.

- The starting point of relatedness and relationship as a result of hearing and Deaf encounters.

- The subject of awareness taken as the problem of the study.

$\square$ - The communicative models by Kreher, Y.W. (2013).

- The respondents of the study.

- The stakeholders of the hospitality industry.

- The sectors of hospitality industry that serves as meeting point for hearing and Deaf encounters.

$\square$ - The particular hospitality establishments covered by the study.

$\square$ - The distinguishing output of the study.

$\square$ - The specific impact and implications of the study. 


\section{Hypothesis}

Hypothesis was tested at 0.05 level of significance. Ho1. There was no significant difference between the respondents' levels of awareness on the Deaf culture and FSL skills in the hospitality industry of Zamboanga City.

\section{RESEARCH METHOD}

\section{Research Design}

This study used the descriptive design employing both qualitative and quantitative approaches. In Qualitative Approach, it described the hearing hospitality stakeholders' communication and interaction patterns in an environment of language exchange occurring in a natural and sensitive encounter in the hospitality industry in Zamboanga City. For this reason, the multi-linguistic approach of Chavacano, Filipino, and English were considered and taken as a prime mover in the proceedings. Quantitatively, on the other hand, the study used an adapted survey questionnaire anchored on the study of Kreher, Y.W. (2013) to determine the awareness of the guests, managers/staff, job seekers and advocates about Deaf culture and Filipino sign language skills in the hospitality industry of Zamboanga City.

\section{Sample Group}

The sample group of the study were selected purposively from the hospitality organizations such as hotels and restaurants - excluding quick-service dining establishments, particularly the fast-food chains, in Zamboanga City. The city has 30 hotels and 187 restaurants based on records of the Zamboanga City Licensing Office as of June 7, 2019. Six (6) hotels, 3 Tourist Inns, 8 pension houses, 1 MICE facility, 1 tourist recreation facility, 1 resort and 14 restaurants were duly accredited by the Regional Office of the Department of Tourism (DOT) Region 9 based on records dated December 31, 2018. Table 1 shows the distribution of the sample group from the various stakeholders in the Hospitality Industry in Zamboanga City.

Table 1. Distribution of Respondents from Various Stakeholders in the Hospitality Industry of Zamboanga City

\begin{tabular}{cccc}
\hline No. & $\begin{array}{c}\text { Hospitality } \\
\text { Industry } \\
\text { Stakeholder }\end{array}$ & Position & Population \\
\hline 1 & & Hotel Manager & 1 \\
2 & & Restaurant Manager & 1 \\
3 & Cafe Manager & 1 \\
4 & & Hotel Maintenance Supervisor & 1 \\
5 & 16 = Workforce & Hotel F\&B Asst. Supervisor & 1 \\
6 & (Managerial/ & Restaurant Cafe Barista Team & 1 \\
7 & Supervisory) & Leader & 1 \\
8 & & Restaurant Cafe Pastry Chef & 1 \\
$9-10$ & & Hotel Housekeeping Supervisor & 2 \\
$11-13$ & & Hotel Sales Executive & 3 \\
$14-16$ & & Hotel Concierge & 3 \\
\hline
\end{tabular}




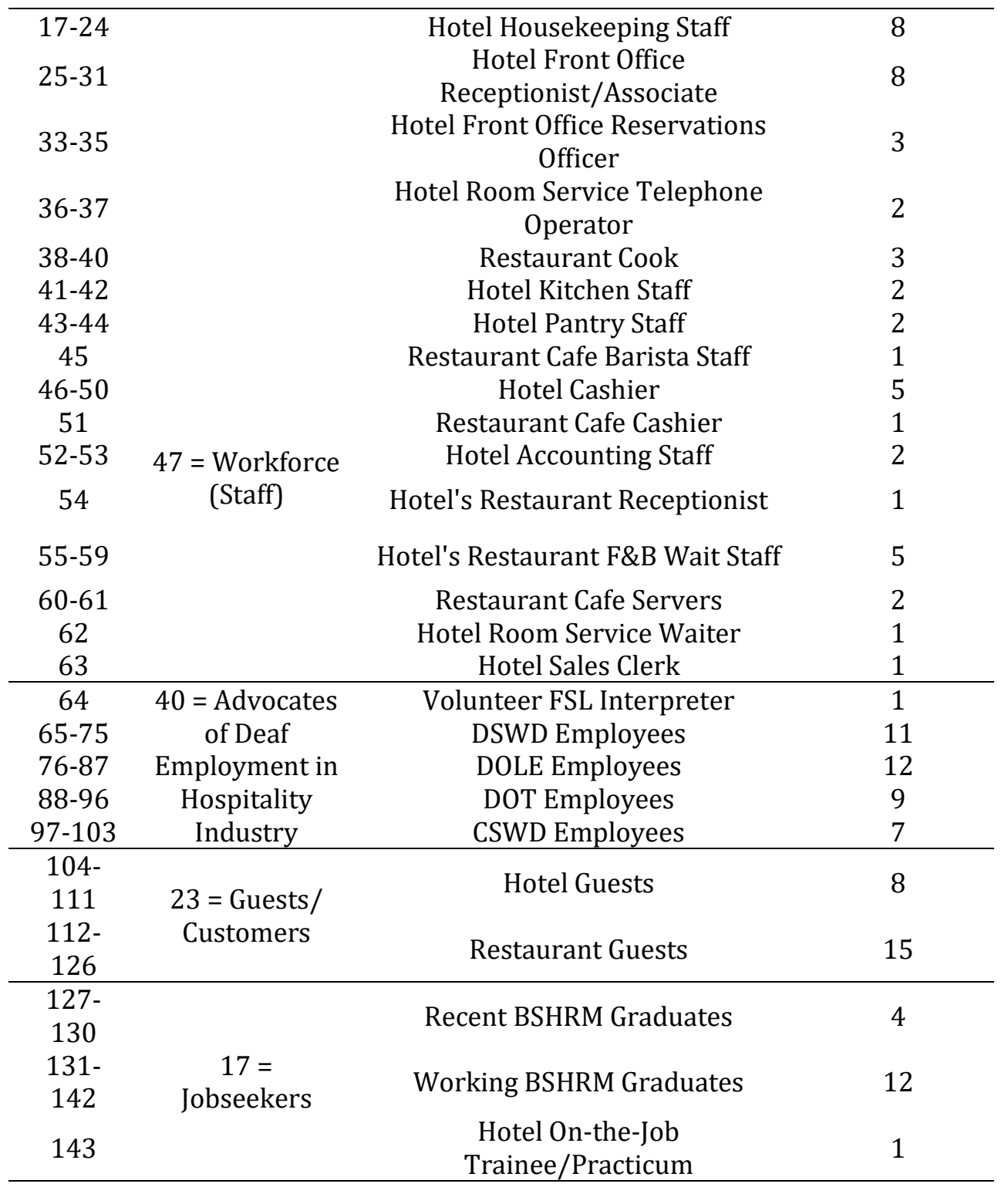

Based on Table 1, 47 respondents belonged to the hospitality workforce who were persons with experience working as staff of a hospitality organization or related establishments in Zamboanga City like the housekeeping staff, front office receptionist or front office reservations officer; 40 respondents belonged to the group of people who advocated Deaf employment in the hospitality industry like the volunteer interpreter, DSWD employees/advocates, or DOLE employees/advocates; 23 respondents belong to the guests and customers of the hotels or restaurants; 17 respondents referred to the job seekers in the hospitality industry, and 16 respondents belonged to the hospitality workforce like the managers or supervisors. 
Table 2. Distribution of the Respondents from the Hospitality Industry and from the Focused Group Discussions

\begin{tabular}{ccccccc}
\hline Category & $\begin{array}{c}\text { Hospitality } \\
\text { Industry } \\
\text { Stakeholder } \\
(\mathrm{N})\end{array}$ & $\begin{array}{c}\text { Percentage } \\
(\%)\end{array}$ & $\begin{array}{c}\text { FGD } \\
\text { Hearing } \\
\text { Participants }\end{array}$ & $\begin{array}{c}\text { FGD Deaf } \\
\text { Participants }\end{array}$ & $\begin{array}{c}\text { Frequency } \\
\text { (N) }\end{array}$ & $\begin{array}{c}\text { Percentage } \\
(\%)\end{array}$ \\
\hline $\begin{array}{c}\text { Hospitality } \\
\text { Workforce } \\
\text { (Manager/ } \\
\text { Staff) }\end{array}$ & 64 & $44.76 \%$ & 3 & 1 & 4 & $33.33 \%$ \\
\hline $\begin{array}{c}\text { Hospitality } \\
\text { Jobseeker }\end{array}$ & 16 & $11.19 \%$ & 1 & 1 & 2 & $16.67 \%$ \\
\hline $\begin{array}{c}\text { Hospitality } \\
\text { Guest/ } \\
\text { Customer }\end{array}$ & 23 & $16.08 \%$ & 0 & 2 & 2 & $16.67 \%$ \\
\hline $\begin{array}{c}\text { Advocates of } \\
\text { Deaf }\end{array}$ & & & & & & \\
$\begin{array}{c}\text { Employment } \\
\text { in the }\end{array}$ & 40 & $27.97 \%$ & 4 & 0 & 4 & $33.33 \%$ \\
$\begin{array}{c}\text { Hospitality } \\
\text { Industry }\end{array}$ & & $\mathbf{1 0 0 \%}$ & $\mathbf{8}$ & $\mathbf{4}$ & $\mathbf{1 2}$ & $\mathbf{1 0 0 \%}$ \\
\hline TOTAL & $\mathbf{1 4 3}$ & & & & & \\
\hline
\end{tabular}

Table 2 shows 12 individuals who were key informants for the in-depth interview which was composed of eight respondents from the hearing group and four from the Deaf group which were distributed as follows: 1) SPED Educator with more than 2 decades of involvement with the Deaf Community in Zamboanga City; 2) a DSWD Region IX Representative with at least 20 years experience in social service, former focal person for PWDs and currently for Family, Women, and Children coordinating with AVRC doing research on PWDs skills-job mismatch, and who has a Deaf brother and sister-in-law; 3) a workforce representative with managerial position, 20-year industry exposure from a pioneering and consistently growing hotel in Zamboanga City, and has experienced supervising Deaf On-the-Job trainees at the hotel; 4) a hospitality workforce representative with staff level position and at least 10-year industry experience as Cook in a restaurant in Zamboanga City, and has experienced working with Deaf co-workers; 5) a workforce representative from the coffee shop where the FGDs took place and who has a first time encounter and the most recent experience encountering Deaf customers/guests being the Cafe's cashier whom the Deaf participants lined up to order their food and drinks; 6) a DOLE Region IX representative who is the focal representative for PWD concerns and is also a member of the PWD community having physical disability herself - limb in particular; 7) a hospitality industry jobseeker being an HRM graduate who had previous encounter dealing with Deaf participants during their class event prior to his graduation - of which he was one of the event organizers; and 8) a Filipino Sign Language Interpreter who has a particular role in interpreting for Special Education (SPED) Senior High School students in their regular classes with the hearing typically subjects such as those related to food service and food preparations. 
Based on Table 2, 44.76 percent or 64 respondents belonged to the hospitality workforce who were persons with experience working as manager or staff of a hospitality organization or related establishments in Zamboanga City; 27.97 percent or 40 respondents belonged to the group of people who advocated Deaf employment in the hospitality industry; 16.08 percent or 23 respondents belonged to the guests and customers of the hotels or restaurants, and 11.19 percent or 16 respondents belonged to the hospitality job seekers in the hospitality industry.

On the other hand, 33.33 percent or three respondents from the hearing participants and one respondent from the Deaf participant in the FGD; 33.33 percent or four respondents from the hearing participants and no respondent from the Deaf participant in the FGD; 16.67 percent or one respondent from the hearing participant and one respondent from the Deaf participant in the FGD; and 16.67 percent or no respondent from the hearing participant and two respondents from the Deaf participant.

Table 3. Distribution of the Interviewees' Profiles from the Hearing Group

\begin{tabular}{|c|c|c|c|c|c|c|c|c|}
\hline No & Pseudonym & Deaf Encounter/s & Education & $\begin{array}{l}\text { Hospitality } \\
\text { Stakeholder } \\
\text { Category }\end{array}$ & Affiliation & Position & Gender & Age \\
\hline 1 & SPED Educator & $\begin{array}{l}23 \text { years with the Deaf } \\
\text { Community in } \\
\text { Zamboanga City as } \\
\text { SPED teacher, FSL } \\
\text { interpreter, and } \\
\text { coordinator for all } \\
\text { private or government } \\
\text { Deaf-related programs }\end{array}$ & $\begin{array}{c}\text { College } \\
\text { Graduate } \\
\text { (not Major } \\
\text { in SPED); } \\
\text { with } \\
\text { exposure to } \\
\text { local, } \\
\text { national and } \\
\text { international } \\
\text { SPED } \\
\text { trainings } \\
\end{array}$ & $\begin{array}{l}\text { Advocate of } \\
\text { Deaf } \\
\text { Employmen } \\
\text { t in } \\
\text { Hospitality } \\
\text { industry }\end{array}$ & $\begin{array}{l}\text { Zamboanga } \\
\text { City High } \\
\text { School } \\
\text { (Main } \\
\text { Campus) }\end{array}$ & $\begin{array}{c}\text { SPED } \\
\text { Coordinator }\end{array}$ & Female & 50 's \\
\hline 2 & $\begin{array}{c}\text { DSWD } \\
\text { Representative }\end{array}$ & $\begin{array}{l}\text { Former focal person } \\
\text { for PWDs and with at } \\
\text { least } 20 \text { years in social } \\
\text { service; has a Deaf } \\
\text { brother and sister-in- } \\
\text { law }\end{array}$ & $\begin{array}{l}\text { College } \\
\text { Graduate }\end{array}$ & $\begin{array}{l}\text { Advocate of } \\
\text { Deaf } \\
\text { Employmen } \\
\text { t in } \\
\text { Hospitality } \\
\text { industry }\end{array}$ & $\begin{array}{l}\text { Departmen } \\
\text { t of Social } \\
\text { Welfare } \\
\text { and } \\
\text { Develop- } \\
\text { ment } \\
\text { Region IX }\end{array}$ & $\begin{array}{l}\text { Researcher } \\
\text { on PWD job } \\
\text { mismatching } \\
\text { and the } \\
\text { Focal person } \\
\text { for Family, } \\
\text { Women, and } \\
\text { Children } \\
\end{array}$ & Female & 40 's \\
\hline 3 & $\begin{array}{c}\text { Hotel } \\
\text { Representative }\end{array}$ & $\begin{array}{l}\text { A pioneering hotel } \\
\text { employee, with at least } \\
10 \text { years industry } \\
\text { exposure, who used to } \\
\text { directly supervise Deaf } \\
\text { On-the-Job trainees/ } \\
\text { practicumers at the } \\
\text { hotel for banquet, } \\
\text { restaurant, and room } \\
\text { service. }\end{array}$ & $\begin{array}{l}\text { Bachelor of } \\
\text { Science in } \\
\text { Hotel and } \\
\text { Restaurant } \\
\text { Management } \\
\text { (BSHRM) } \\
\text { graduate }\end{array}$ & Workforce & $\begin{array}{c}\text { Grand } \\
\text { Astoria } \\
\text { Hotel, } \\
\text { Zamboanga } \\
\text { City }\end{array}$ & $\begin{array}{l}\text { Lotus } \\
\text { Restaurant } \\
\text { Supervisor }\end{array}$ & Female & 40 's \\
\hline 4 & $\begin{array}{l}\text { Restaurant } \\
\text { Representa- } \\
\text { tive }\end{array}$ & $\begin{array}{c}\text { A pioneering } \\
\text { employee, with at least } \\
10 \text { years of industry } \\
\text { exposure, who used to } \\
\text { be a co-worker of two } \\
\text { former Deaf employees }\end{array}$ & $\begin{array}{l}\text { High School } \\
\text { graduate }\end{array}$ & Workforce & $\begin{array}{l}\text { Tsokolate } \\
\text { Restaurant } \\
\text { by LinFood }\end{array}$ & Senior Cook & Male & 30 's \\
\hline
\end{tabular}




\begin{tabular}{|c|c|c|c|c|c|c|c|c|}
\hline & & $\begin{array}{l}\text { at the restaurant he is } \\
\text { still connected with. }\end{array}$ & & & & & & \\
\hline 5 & $\begin{array}{c}\text { Cafe } \\
\text { Representative }\end{array}$ & $\begin{array}{l}\text { A cashier at the coffee } \\
\text { shop where the FGD } \\
\text { participants lined up to } \\
\text { order their food and } \\
\text { drinks; one with the } \\
\text { most recent first } \\
\text { encounter with Deaf } \\
\text { customers. }\end{array}$ & $\begin{array}{c}\text { Technical- } \\
\text { Vocational } \\
\text { School: } 2-y r \\
\text { Hotel and } \\
\text { Restaurant } \\
\text { Management } \\
\text { (HRM) } \\
\text { program } \\
\text { graduate } \\
\end{array}$ & Workforce & $\begin{array}{l}\text { Coffee } \\
\text { Hour } \\
\text { (Tetuan } \\
\text { Branch) }\end{array}$ & Cashier & Female & 20 's \\
\hline 6 & $\begin{array}{c}\text { DOLE } \\
\text { Representative }\end{array}$ & $\begin{array}{l}\text { Deaf encounters } \\
\text { during her designation } \\
\text { as the focal person for } \\
\text { PWD concerns; herself, } \\
\text { a member of the PWD } \\
\text { community being limb } \\
\text { (physical disability) }\end{array}$ & $\begin{array}{l}\text { College } \\
\text { Graduate }\end{array}$ & $\begin{array}{l}\text { Advocate of } \\
\text { Deaf } \\
\text { Employmen } \\
\text { t in } \\
\text { Hospitality } \\
\text { industry }\end{array}$ & $\begin{array}{c}\text { Departmen } \\
\text { t of Labor } \\
\text { and } \\
\text { Employme } \\
\text { nt Region } \\
\text { IX }\end{array}$ & $\begin{array}{l}\text { Labor } \\
\text { Officer, } \\
\text { Technical } \\
\text { Support } \\
\text { Services } \\
\text { Division }\end{array}$ & Female & 30 's \\
\hline 7 & Jobseeker & $\begin{array}{l}\text { Had accommodate } \\
\text { Deaf participants } \\
\text { during their class } \\
\text { event during his final } \\
\text { semester in college, } \\
\text { being one of the event } \\
\text { organizers }\end{array}$ & $\begin{array}{l}\text { Bachelor of } \\
\text { Science in } \\
\text { Hotel and } \\
\text { Restaurant } \\
\text { Management } \\
\text { (BSHRM) } \\
\text { graduate }\end{array}$ & Jobseeker & None & $\begin{array}{c}\text { Recent } \\
\text { BSHRM } \\
\text { graduate }\end{array}$ & Male & 20 's \\
\hline 8 & $\begin{array}{c}\text { FSL } \\
\text { Interpreter }\end{array}$ & $\begin{array}{l}\text { Exposure to Deaf } \\
\text { community since her } \\
\text { college years being } \\
\text { Special Education } \\
\text { (SPED) Major student } \\
\text { and as a volunteer "In- } \\
\text { Classroom" sign } \\
\text { language interpreter } \\
\text { for SPED Senior High } \\
\text { School students in } \\
\text { hearing group. } \\
\end{array}$ & $\begin{array}{l}\text { Bachelor of } \\
\text { Science in } \\
\text { Elementary } \\
\text { Education - } \\
\text { Major in } \\
\text { Special } \\
\text { Education } \\
\text { (SPED) }\end{array}$ & $\begin{array}{l}\text { Advocate of } \\
\text { Deaf } \\
\text { Employmen } \\
\text { t in } \\
\text { Hospitality } \\
\text { industry }\end{array}$ & None & $\begin{array}{l}\text { Volunteer, } \\
\text { Filipino Sign } \\
\text { Language } \\
\text { (FSL) and } \\
\text { Signing } \\
\text { Exact } \\
\text { English } \\
\text { (SEE) } \\
\text { Interpreter }\end{array}$ & Female & 20 's \\
\hline
\end{tabular}

Table 3 shows the distribution of the interviewees' profiles from the hearing group interviewed during the focus group discussion.

Based on Table 3, the 8 respondents from the hearing group were SPED educators, DSWD Representatives, Hotel representatives, Restaurant representatives, Café Representatives, DOLE Representatives, Jobseekers and Interpreters. On the other hand, Table 4, below, shows the distribution of the interviewees' profiles from the Deaf group.

Table 4. Distribution of the Interviewees Profile from the Deaf Group

\begin{tabular}{|c|c|c|c|c|c|c|c|c|c|}
\hline No & $\begin{array}{l}\text { Pseu- } \\
\text { donym }\end{array}$ & Profile & Education & $\begin{array}{l}\text { Hospitality } \\
\text { Stakeholder } \\
\text { Category }\end{array}$ & $\begin{array}{c}\text { Degree of } \\
\text { deafness }\end{array}$ & $\begin{array}{l}\text { Hearing/ } \\
\text { Speaking } \\
\text { Abilities }\end{array}$ & $\begin{array}{l}\text { Hearing/ } \\
\text { Speaking } \\
\text { Abilities }\end{array}$ & Gender & Age \\
\hline 1 & Deaf 1 & $\begin{array}{c}\text { Former } \\
\text { restaurant } \\
\text { dishwasher }\end{array}$ & $\begin{array}{l}\text { SPED High } \\
\text { School } \\
\text { graduate }\end{array}$ & Workforce & $\begin{array}{l}\text { Hard of } \\
\text { Hearing }\end{array}$ & $\begin{array}{l}\text { Only able to } \\
\text { hear when he is } \\
\text { able to establish } \\
\text { eye contact; can } \\
\text { speak a lot but }\end{array}$ & $\begin{array}{l}\text { Very extrovert } \\
\text { and } \\
\text { communicates } \\
\text { to anyone he } \\
\text { can do so }\end{array}$ & Male & 35 \\
\hline
\end{tabular}




\begin{tabular}{|c|c|c|c|c|c|c|c|c|c|}
\hline & & & & & & $\begin{array}{c}\text { can only } \\
\text { communicate } \\
\text { when he is able } \\
\text { to lip read }\end{array}$ & & & \\
\hline 2 & Deaf 2 & $\begin{array}{c}\text { Former } \\
\text { Practicumer/ } \\
\text { On-the-Job } \\
\text { Trainee (OJT) } \\
\text { at a hotel and } \\
\text { restaurant }\end{array}$ & $\begin{array}{l}\text { SPED } \\
\text { College } \\
\text { graduate } \\
\text { specializing } \\
\text { in Food } \\
\text { Service }\end{array}$ & Jobseeker & $\begin{array}{l}\text { Profound- } \\
\text { ly Deaf }\end{array}$ & $\begin{array}{c}\text { Cannot hear nor } \\
\text { speak at all }\end{array}$ & $\begin{array}{c}\text { Socializes } \\
\text { when he is } \\
\text { understood or } \\
\text { if any person } \\
\text { shows interest } \\
\text { in talking to } \\
\text { him } \\
\end{array}$ & Male & 43 \\
\hline 3 & Deaf 3 & $\begin{array}{l}\text { Technical } \\
\text { Education } \\
\text { and Skills } \\
\text { Development } \\
\text { Authority } \\
\text { National } \\
\text { Competency } \\
\text { II (TESDA NC } \\
\text { II) holder on } \\
\text { Housekeeping } \\
\text { Services and } \\
\text { Bread \& } \\
\text { Pastry } \\
\text { Production } \\
\text { with WMSU } \\
\text { Hostel } \\
\text { practicum } \\
\text { experience } \\
\end{array}$ & $\begin{array}{l}\text { SPED } \\
\text { Senior High } \\
\text { School } \\
\text { graduate; } \\
\text { to enroll in } \\
\text { college }\end{array}$ & $\begin{array}{l}\text { Customer/ } \\
\text { Guest }\end{array}$ & $\begin{array}{l}\text { Hard of } \\
\text { Hearing }\end{array}$ & $\begin{array}{c}\text { Can hear and } \\
\text { speak a little bit } \\
\text { but only } \\
\text { communicates } \\
\text { through sign } \\
\text { language by } \\
\text { personal choice; } \\
\text { she does speak } \\
\text { but only in the } \\
\text { comfort of her } \\
\text { own home; } \\
\text { consequentially, } \\
\text { an introvert for } \\
\text { being excluded } \\
\text { from society }\end{array}$ & $\begin{array}{l}\text { Very introvert } \\
\text { and would only } \\
\text { engage in } \\
\text { communication } \\
\text { if necessarily }\end{array}$ & $\begin{array}{l}\mathrm{Fe}- \\
\text { male }\end{array}$ & 20 \\
\hline 4 & Deaf 4 & $\begin{array}{l}\text { Technical } \\
\text { Education } \\
\text { and Skills } \\
\text { Development } \\
\text { Authority } \\
\text { National } \\
\text { Competency } \\
\text { II (TESDA NC } \\
\text { II) holder on } \\
\text { Housekeeping } \\
\text { Services and } \\
\text { Bread \& } \\
\text { Pastry } \\
\text { Production } \\
\text { with WMSU } \\
\text { Hostel } \\
\text { practicum } \\
\text { experience }\end{array}$ & $\begin{array}{l}\text { SPED } \\
\text { Senior High } \\
\text { School } \\
\text { graduate; } \\
\text { to enroll in } \\
\text { college }\end{array}$ & $\begin{array}{l}\text { Customer/ } \\
\text { Guest }\end{array}$ & $\begin{array}{l}\text { Profound- } \\
\text { ly Deaf }\end{array}$ & $\begin{array}{c}\text { Cannot hear nor } \\
\text { speak at all }\end{array}$ & $\begin{array}{l}\text { Very extrovert } \\
\text { and has a lot of } \\
\text { hearing friends }\end{array}$ & $\begin{array}{l}\mathrm{Fe}- \\
\text { male }\end{array}$ & 21 \\
\hline
\end{tabular}

Based on Table 4, the profiles of the four Deaf interviewed during the focus group discussion were: 1) a Deaf who was formerly working as a dishwasher at a Restaurant located in Zamboanga City; 2) a former Food Service SPED graduate who had the On-the-Job trainings at a restaurant and banquet service operations at hotel in Zamboanga City; 3) a SPED Senior High School (SHS) graduate who was a TESDA NC-II holder in Bread and Pastry, Food and Beverage, Front Office Services whereby competency assessments were taken with hearing participants - all of which were skills or qualifications for work in the hospitality industry; a respondent who has very

82 
minimal exposure to or extracted from the hearing community; and, 4) also a SPED Senior High School (SHS) graduate who was a TESDA NC-II holder in Bread and Pastry, Food and Beverage, Front Office Services whereby competency assessments were taken with hearing participants - all of which were skills or qualifications for work in the hospitality industry; but an extrovert Deaf individual who has a lot of exposure with the hearing community. Records from the Zamboanga City Social Welfare and Development (CSWD) showed that there were 440 registered Deaf individuals out of 4,994 Persons With Disabilities (PWDs) as of May 27, 2019 in Zamboanga City. However, a tracer study has yet to be conducted to know the whereabouts of the hearing-impaired individuals in Zamboanga City's Deaf community which was described to be very large by one of the study's FGD (hearing group) participant.

\section{Instrumentation and Validation}

The main instrument of the study was an adapted survey questionnaire checklist from Kreher, Y.W. (2013). It was composed of three parts: the first part pertained to the respondents' position in the hospitality industry; the second part pertained to the respondents' levels of awareness of the Deaf culture; and, the third part pertained to the respondents' levels of awareness on FSL.

\section{Validity and Reliability}

The adapted survey questionnaire checklists were validated by an expert FSL interpreter and Deaf specialist, while its reliability was pre-tested by 20 non-respondents of the study. This made certain that the questions formed were clearly and specifically related to the problems set in the study. Furthermore, the other instruments of the study were observation and interview guide which were used in two focused group discussions with a hearing group composed of 8 participants and a Deaf group composed of 4 Deaf participants and 1 hearing interpreter. For the in-depth interview and observations, all were transcribed and recorded using both videos with the encrypted audio recording while the whole processes were in progress.

\section{Thematic Analysis}

The thematic analysis of this study had two parts - one for the hearing FGD and the other one for the Deaf FGD. During the interview, the researcher asked questions leading to the natural expression, interaction, and interplay during the focused group discussion. In the process, the researcher recorded the whole interview that lasted from 5 to 6 hours. During transcription, the researcher noted all the details that included the exchanges of discussion, negation, affirmation, and clarification. Coding was done after a thorough reading of details and understanding the main subject of the entire interaction and interactive discussion. After which, the researcher analyzed the subject matter of each presentation, opinions, suggestions, arguments, and defenses. In relation to the thematic analysis of the Deaf FGD, the same process was applied. However, there was a volunteer interpreter present to assist in the facilitation of the exchange of views in progress. The FSL skills were noted very carefully so that each concluded discussion was noted with a correct theme notation. This is to tie up the descriptive intention of the expected outcome based on the guided questions asked. In addition, the specific significant statements of the interview participants were carefully noted as well to get the impact of the inner thought and feelings of the members of 
the FGD. Hence, the thematic analysis was subjected to the coding process whereby coherence was observed - unifying the general insights that took place in the course of the interview leading to the specific meaning or core of the discussion and arriving at the expected outcome of such FGD. This means that congruency and parallelism were achieved.

\section{Data Gathering Procedures}

The data gathering procedures began with an ocular visit to the selected hospitality organizations in Zamboanga City to do an initial interview and to note down an overview of the facilities. After which, written permission was made for this study. It was addressed to the head of the hospitality organization so that proper communication could be substantially carried out and solicit the cooperation of the target respondents. Specifically, the research method was centred on the following: questionnaire checklist for the quantitative method; observation, fieldwork, participation, interview, focused group discussion, documentation, and transcription for the qualitative method.

For the quantitative data gathering, the questionnaires were handed to a point person for every concerned hospitality or government organization, and the accomplished questionnaire checklists were collected from the same person a day or two after depending on what has been agreed by both parties. For the qualitative data gathering, the interview was conducted at an agreed meeting location that lasted for at least two hours. To ensure the timeliness of the arrival of the participants, the Deaf participants were asked to come at 1:00 PM, and the interview started at 1:30 PM. due to the late arrival of the interpreter. The hearing participants were requested to arrive at 3:00 PM. The venue was a new coffee shop in the present researcher's town of Tetuan. The interviews were very productive, and the initial recordings produced were not ideal and harder to transcribe into text, but the present research sought help from a movie editing expert from the United States to have the audios corrected and enhanced for better clarity and volume. All prospective participants were first given a copy of the written consent form and were requested to sign in the attendance sheet. All hearing participants were also given questionnaire checklists to accomplish.

The researcher described the interview process and the study details, discussed the confidentiality issues with all the participants before the commencement of each interview session and gave them time to read the consent form as well as the opportunity to raise questions or concerns before and at any point during the interview process. The researcher proceeded with the interview after the consent was given with each participant's signature affixed on their respective consent forms, followed by the signing of the present researcher on the same form and giving them a copy of the accomplished form for future reference. Once the participants felt comfortable and ready to proceed, the digital recording began along with the interview process.

The video recording was converted to an audio version while keeping the original for transcription purposes. With that, the researcher was able to produce a written record of the interview, with identifying information replaced with pseudonyms that were adopted for writing of which were assigned by the present researcher according to the best representation description of the participants. Such methods were centered in terms of interaction and communication processes while the natural occurrences were being established. Such scenarios were done to determine the viability and accessibility of the target activities. In the process, the transcription 
method of digital video recording or coverage was used for the reliability of the given study. And, the questionnaire checklists were distributed at the end of the interview, and the same was retrieved immediately after.

\section{Statistical Treatment of Data}

The statistical treatment used in the study were the frequency, percentage, mean standard deviation, and Analysis of Variance (ANOVA). The Mean was utilized to determine the measure of central tendency on the perception of the respondents about the level of awareness of the Deaf culture and FSL skills. The standard deviation was used to determine the variability of the responses of the respondents in this study. Analysis of Variance (ANOVA) was used to test the significant difference in the ratings between the group of respondents.

\section{FINDINGS AND DISCUSSION}

\section{Level of Awareness of Hearing Hospitality Stakeholders on Deaf Culture}

The stakeholders in the Hospitality industry of Zamboanga City were aware of Deaf people with a grand mean of 2.68. Table 5 presents the level of awareness on Deaf culture of the stakeholders in the hospitality industry of Zamboanga City.

Table 5. Level of Awareness on Deaf Culture of the Stakeholders in the Hospitality Industry in Zamboanga City.

\begin{tabular}{lccc}
\hline \multicolumn{1}{c}{ Statements } & Mean & $\begin{array}{c}\text { Standard } \\
\text { Deviation }\end{array}$ & Interpretation \\
\hline $\begin{array}{l}\text { 1. may be referred to as Capital "D" } \\
\text { Deaf as a culture and small "d" } \\
\text { deaf for pathology. }\end{array}$ & 1.93 & 0.10 & $\begin{array}{c}\text { Moderately } \\
\text { Aware }\end{array}$ \\
\hline 2. have a culture of their own. & 2.67 & 0.46 & Aware \\
\hline $\begin{array}{l}\text { 3. may have the tendency to dislike } \\
\text { or disapprove wearing a hearing } \\
\text { aid, particularly when it becomes } \\
\text { offensive due expectations of } \\
\text { people around them. }\end{array}$ & 2.57 & 0.40 & Aware \\
\hline $\begin{array}{l}\text { 4. prefer to be with other members } \\
\text { of the Deaf community or join deaf } \\
\text { clubs or societies. }\end{array}$ & 2.80 & 0.47 & Aware \\
\hline $\begin{array}{l}\text { 5. tend to be grateful, loyal and } \\
\text { honest when treated well or feel } \\
\text { privileged. }\end{array}$ & 3.16 & 0.73 & Aware \\
$\begin{array}{l}\text { 6. can be assets to a company with } \\
\text { high potential of excellence if } \\
\text { given the chance. }\end{array}$ & 2.94 & 0.58 & Aware \\
\hline $\begin{array}{l}\text { 7. have the tendency to get irritable } \\
\text { when they are not understood. }\end{array}$ & 2.68 & 0.43 & Aware \\
\hline $\begin{array}{l}\text { 8. may become depressed because } \\
\text { of self-pity, insecurity, or when }\end{array}$ & 2.64 & 0.39 & \\
\hline
\end{tabular}




\begin{tabular}{lccc}
\hline $\begin{array}{l}\text { separated from the Deaf } \\
\text { community. }\end{array}$ & & & \\
\hline $\begin{array}{l}\text { 9. some Deaf individuals are Hard } \\
\text { of Hearing (have some degree of } \\
\text { hearing capacity). }\end{array}$ & 2.89 & 0.58 & Aware \\
$\begin{array}{l}\text { 10. who can lip-read are not born } \\
\text { Deaf. }\end{array}$ & 2.56 & 0.33 & Aware \\
\hline \multicolumn{1}{c}{ Grand Mean } & $\mathbf{2 . 6 8}$ & Aware
\end{tabular}

Scale: 4.00 - 3.25 Fully Aware; 3.24 -2.50 Aware; 2.49 - 1.75 Moderately Aware; and 1-74 - 1.00 Unaware

Based on Table 5, the hospitality stakeholders of Zamboanga City were aware that Deaf people tend to be grateful, loyal and honest when treated well or feel privileged with a mean of 3.16, while the stakeholders were only moderately aware that Capital "D" Deaf refers to culture and small "d" refers to pathology with a mean of 1.93. These findings were parallel to Senghas, R. J., \& Monaghan, L. (2002), who typically described deafness as a pathology, focusing on cures or mitigation of the perceived handicap until 25 years back and that anthropological researchers have approached the study of d/Deaf communities differently.

\section{Level of Awareness of Hearing Hospitality Stakeholders on Filipino Sign Language}

The stakeholders of the Hospitality industry in Zamboanga City were aware of the Filipino Sign Language with a grand mean of 2.73. Table 6 shows the level of awareness on Filipino Sign Language by the Stakeholders of the hospitality industry in Zamboanga City.

Table 6. Level of Awareness of Filipino Sign Language by the Stakeholders in the Hospitality Industry of Zamboanga City.

\begin{tabular}{|c|c|c|c|}
\hline Statements & Mean & $\begin{array}{l}\text { Standard } \\
\text { Deviation }\end{array}$ & Interpretation \\
\hline $\begin{array}{l}\text { 1. learn sign language - Filipino Sign language } \\
\text { (FSL) in the Philippines - through proper } \\
\text { training in school or accessible formal } \\
\text { training and not from home. }\end{array}$ & 3.00 & 0.64 & Aware \\
\hline $\begin{array}{l}\text { 2. can visually communicate with the hearing } \\
\text { through reading, writing or gestures. }\end{array}$ & 3.11 & 0.72 & Aware \\
\hline $\begin{array}{l}\text { 3. have grammar and express their thoughts in } \\
\text { whole sentences using Filipino Sign } \\
\text { Language - not just root words. }\end{array}$ & 2.70 & 0.42 & Aware \\
\hline $\begin{array}{l}\text { 4. communicate in, mostly, English - as learned } \\
\text { in school. }\end{array}$ & 2.78 & 0.45 & Aware \\
\hline $\begin{array}{l}\text { 5. use facial expressions to convey punctuations } \\
\text { in their signs and gestures. }\end{array}$ & 2.88 & 0.56 & Aware \\
\hline $\begin{array}{l}\text { 6. use visuals like blinking lights to catch } \\
\text { someone's attention from a distance. }\end{array}$ & 2.58 & 0.38 & Aware \\
\hline $\begin{array}{l}\text { 7. use respond to rhythmic patterns or impact } \\
\text { of sounds in the surrounding. }\end{array}$ & 2.29 & 0.23 & $\begin{array}{l}\text { Moderately } \\
\text { Aware }\end{array}$ \\
\hline
\end{tabular}


Tourism and Sustainable Development Review Journal (TSDR), Vol. 2 (2), 71-96

Filipino Sign Language Skills and Deaf Culture Awareness in Hospitality Industry Employability

Ma. Aurora C. Niebla

\begin{tabular}{llcc}
\hline $\begin{array}{l}\text { 8. utilize emotions to express their feelings } \\
\text { when communicating with the hearing. }\end{array}$ & 2.77 & 0.45 & Aware \\
\hline $\begin{array}{l}\text { 9. differ in sign language and culture depending } \\
\text { upon their territory. }\end{array}$ & 2.58 & 0.37 & Aware \\
\hline $\begin{array}{c}\text { 10. are mostly not mute and the mute } \\
\text { individuals are not necessarily deaf. }\end{array}$ & 2.61 & 0.38 & Aware \\
\hline Grand Mean & $\mathbf{2 . 7 3}$ & & Aware \\
\hline
\end{tabular}

Scale: 4.00 - 3.25 Fully Aware; 3.24 -2.50 Aware; 2.49 - 1.75 Moderately Aware; and 1-74 1.00 Unaware

Based on Table 6, the stakeholders were aware that Deaf people could visually communicate with the hearing individuals through reading, writing or gestures with a mean of 3.11, while the stakeholders were only moderately aware that Deaf people respond to rhythmic patterns or the impact of sounds in their surroundings with a mean of 2.29 .

The findings were in agreement with Nordqvist, C. (2018, Jun 27) that sign language uses signs with hands, facial expressions, and body postures. Hiddinga, A., \& Crasborn, O. (2011) stated that Deaf people who form part of a Deaf community communicate using a shared sign language.

\section{Category of Communication}

All hearing individuals are Border Crossers who may get involved with Deaf individuals regardless of their intent or situation. Based on the interview with the Deaf and hearing individuals, they claimed that attitude has a crucial role in the failure and success of communication among border crossers.

On questions asked to the hearing stakeholders regarding their perception and understanding of Deafness, one revelation was that most Deaf individuals engage in recreational activities while there were those who were passive. The following excerpts were presented on Deaf self-disclosure: "I do nothing; I'd rather stay at home"; "I love K-Drama"; "I love volleyball"; "I am hard of hearing, I depend on lip reading and eye contact, I love music, I love watching movies with subtitles, I learn to play guitar by watching YouTube."

Parallel to the statement of the hard of hearing on his dependence on lip reading and eye contact, Nordqvist, C. (2018, Jun 27) said that some people are severely deaf and rely on lip-reading to communicate; people who are profoundly deaf can hear nothing at all and can find themselves totally reliant on lip-reading or sign language. In support of these, an article on Deaf hobbies stated that being deaf or hard of hearing shouldn't stand in the way of anyone enjoying or discovering new hobbies \& activities, according to Disability Info South Africa (2016). Meanwhile, on the basis of interactions according to the Deaf individuals' perception on encounters with the hearing revealed that attitude played a crucial role in the successful engagement of Deaf to hearing individuals in any opportunity of an encounter. Significant discussions are as follows: "Interaction with the hearing people depends on their attitude; I prefer the hearing people with a good attitude."; "if Deaf and hearing are friends, they jive with the same attitude or meaning hearing have a good attitude."

In agreement with Nordqvist, C. (2018, Jun 27)'s definition of hearing impairment, deafness, or hearing loss as the total or partial inability to hear sounds, the hearing individuals' perception of Deafness uncovered that it was just the loss of hearing or incapacity to hear. In addition, it did not 
make them incapacitated or disabled individuals. In a similar perspective, it was said that hearing individuals have also been seen with considerable disabilities in terms of not being able to do some of the things that the Deaf can do; the following significant statements as translated were imparted: Deaf but individuals who just lost their hearing capacity as Deaf; we cannot say that they are disabled since they only lack one disability. just call them persons with disability [PWD]]; we [hearing] are complete with all 5 senses, but there are things that they can do that we cannot.. we have our own disability.

In related articles, Himor, J.P. (2018, Oct 12) wrote that persons with disabilities (PWDs) are often disadvantaged when it comes to getting hired and Senghas, R. J., \& Monaghan, L. (2002) stated that deaf people have been marked as different and treated problematically by their hearing societies because of their deafness. Moreover, O'Grady, C. (2018, Nov 01) stated that people who are deaf or hard of hearing are more likely to face discrimination in the workplace as a result of the language barrier." In support of these statements is the discriminatory experience shared by one of the hearing respondents during the interview, as translated: One store here in Yubenco [mall] did not give the 20\% VAT discount privilege; I really stood for my [Deaf] brother; the law is the only thing that can protect them;

This incident is a violation of the RA 10754 which states that twenty percent (20\%) discount and Value Added Tax (VAT) Exemption are to be given to PWDs on the purchase of certain goods and services from all establishments for their exclusive use, enjoyment or avail; Provided, however, that the purchase of such goods and services from sellers that are not subject to Value Added Tax (VAT) shall be subject to the applicable percentage tax Dandee (C 2009 - 2012). In contrast, the insights of other hearing participants on discrimination were surprisingly pro-equality as presented by the foregoing testimonies, as translated: I don't know how to sign, but there are ways to communicate with the Deaf. so we should accept and respect the differences; for sure we [hearing] know that there is something lacking in them; we are complete, so we need to help them and adjust with them; bullying is very evident in society which they will feel discriminated; for equality among us, we should treat them as to how we want to be treated.

A better understanding of this paradigm is associated with the assertion of Case, B. A. (2000), stating that introducing hearing students to Deaf culture allows them to examine their similarities as a person with just a different culture, history, and life experiences. On the other hand, there was evidence of intentional long-term involvement by Deaf individuals with the hearing and vice-versa, while there was still a case of temporary involvement from one respondent, with translation: "Yes, making friends with hearing people makes me happy. But, if they cannot, I am fine with it." ; "Yes. I want to make friends with the hearing people." ; "In my case this is a calling, it becomes passion." ; "I want to break those walls and build bridges to attain communication; actually, I'm not closing any doors, the world is small.. we will really have opportunities to encounters with them [Deaf]; I really volunteered myself to join the sign language training; I really want to understand, be able to give services to them [Deaf] which is because of my advocacy as a social worker and having a Deafbrother; I can see their community; it is not just because it is a job responsibility; the engagement with them [Deaf] should be from the heart"; sometimes I bond with them [Deaf co-employees] but my job is my focus.

Congruent to these statements is the actual occurrence of hearing individuals within hospitality workplaces engaging with the Deaf community through Deaf culture awareness training 
to eliminate communication barriers; such reality exists when KFC staff attend Deaf awareness talks to help them dispel misconceptions about deafness according to Chuang, P. M. (2012, Mar 26) and which is supported by Peters, S. W. (2007) in a similar topic stating that counsellors who have an understanding of Deaf individuals through their history, language, and other important considerations may be better prepared to work with this unique and disregarded. On the other hand, there may not be enough advocacy; according to Stokar, H. (2017), workplace accommodation is still a problem for deaf employees and their managers. She stated that many challenges are the result of communication misinterpretations that can be solved through much needed -although often absent - advocacy and training. Similarly, Coco-Ripp, J. (2003) stated that one way to create a more welcoming or inclusive recreation environment for persons who are deaf or hard of hearing is to redesign the training provided for staff and volunteers who provide recreation services.

On questions asked to the hearing regarding their knowledge of basic sign language, if it was easy for them to understand a Deaf individual's direction/ instruction, and what they do if their effort to communicate with them is not successful, whereby questions for the Deaf were reversed in relation to their basic English words and comprehension, it revealed that the foundation of Deaf individuals' sign language skills relied on where or how they have acquired it which consequentially affected the formality or informality of their gesture and sign attributes; these have been divulged in the foregoing statements, with translation: "FSL is the mother tongue of the Deaf, if the deaf Children of Deaf [Adults] (CODA); if the parents of the deaf are hearing, of course they will verbally talk; so when these children of the hearing parents will go to school, that is where they will learn sign language"; "It is okay if Deaf learn sign language in school but if not their signs become funny or informal.

In support of these statements, the ability of a Deaf person to communicate in sign language reflects the level of his or her involvement within the Deaf community, according to Padden (1989) as cited by Arboleda, R. J. I. (2007). This is said because Case, B. A. (2000) stated that signed language is undoubtedly the most visible and most central shared element of Deaf culture, and that is evident in all aspects of the community and is, in fact, the foundation of the Deaf culture itself. According to The Pulse (2017), as cited by Patigayon, L., S.N. (2018) cited reinforces this point with his statement, "even knowing a little bit of sign goes a long way in establishing rapport with someone who is deaf." Similarly, Uber launched a campaign to teach passengers basic signs so they can say "hello," "thank you," and fingerspell their names to the thousands of ASL-using drivers employed by the ride-sharing company in more than 200 American cities and around the world. Feigenbaum, P. (2017, Oct 16). Local governments have tied up with pro-Deaf organizations such as that of Naga City Interpreters Federation that conducted an inclusive sign language training for government agencies, according to Gunay, A. (2018, July), denoting support to the sign language awareness bandwagon.

On questions asked towards the hearing as to whether they have noticed and understand why Deaf individuals communicate with emphasized facial expressions combined with emphasized gestures when they are angry, happy, sad or need help, whereby questions for the Deaf were reversed in relation to their insights towards the hearing, both their statements were parallel to the statements expressed in related studies such as "non-verbal behaviors are quite important to a person who is Deaf; communication through sign language involves a great deal of facial expression, 
body and hand movements and closed proximity to others" according to Andrews et al., 2004; McEntee, 1993; Scheetz, 2004; Williams \& Abeles, 2004 as cited by Peters, S. W. (2007) relating to Glickman (1996) as cited by Peters, S. W. (2007) who found that clients who are deaf generally held eye contact for a full 5 seconds compared with 1 second for hearing clients. The excerpts from the interview were as follows, with translation: It is important to have facial expressions [to relay message] because the text has no feelings even we do not know sign language; just like that [shows an angry face], a baby would know if you are angry; Deaf are very appreciative of hearing who know signs or even gestures or write on their arms like their destination [Talon-Talon] and show it to the tricycle driver; sometimes, your arms become your paper"; or by texting [messages] through the use of cell phone"; it's a combination for me; if you can't manage using signs, you have to facilitate with written; but, most of all, it's expressions [facial or movement].

On questions regarding the hearing individuals' observations and experiences on Deaf attitude or behavior during interaction with hearing individuals, particularly when a Deaf approaches a hearing stranger and when they are in a group or society where a Deaf individual is involved, whereby questions for the Deaf were reversed to their insights towards the hearing, questions for both the hearing and the Deaf on their interpretation of the phrase "action speaks louder than words, their observations and experiences coincide with Saqueton, G. \& Uychoco, M. (2016) statement on Filipino culture being wordy in written communication but in the case of Deaf individuals, they tend to be concise, constructing short and simple sentences through sign language but emphatic in their expression of ideas. This is evident in the statements (translated) expressed by hearing respondents such as: Even though the Deaf choose English words, they don't [use] its grammar; For example: "I inform you that [Deaf brother] is new working at.. and he happy; their [Deaf's] sentence structure is unlike ours; for them, the sense is there, but the words seem everywhere because they do not follow any subject-verb agreement; for them, it's how they express their message, and it's up for us to interpret it.

On the other hand, Andrews et al. (2004), as cited by Peters, S. W. (2007) stated that it consequentially makes them feel a sense of kinship from Deaf clubs or groups in whom they share this label and makes them see themselves as "cultural minority who choose to use sign language and associate primarily with other Deaf people." This is congruent to the statements given by hearing respondents, translated as such: in our office, every time there is a Deaf client, they go directly to me because they know that I have a Deaf brother; they assume that I can communicate; they talk right away. quickly; unlike the hearing who will observe first before approaching [me])." ; (What ma'am [DSWD Rep] is saying is really true.

On the final question on what can the respondents say about the current situation of Deaf community in Zamboanga City, they asserted that: in other countries like Singapore, the ones serving in us were Deaf, elderly, and blind. The [Filipino Deaf] waiter asked, "how is our country, do to us?"

This is parallel to the statement by Chuang, P. M. (2012, Mar 26), who wrote that a 26-year veteran hotelier in Singapore, Ms Fauziah, trains handicapped individuals in housekeeping duties and prepares them for future careers in Holiday Inn Orchard and in the hospitality industry. A statement by a hearing interpreter respondent revealed that Deaf could manage housekeeping tasks given these statements, as translated: for Front Office Services telephone skills competency, the Deaf is holding the phone, and I told them you need to sign [so she can interpret]. I then said it is better if I will hold the phone so you can sign, and I will be able to talk on the phone what you sign. That's 
what we did"; even in taking orders, they will sign "knocking the door" so I will say "knock-knock" because they are carrying the tray and other [things]; I am the one saying "good morning; that is for Food and Beverage Services because Housekeeping Services they [Deaf] can manage."

These, however, are in contrast to the statements in the article TESDA assures the best care for PWDs (2015, Jun 7) that Technical Education and Skills Development Authority (TESDA)'s incumbent Director General Joel Villanueva said that they are conducting a Sensitivity Training and Basic Sign Language Course at the TESDA Women's Training Center with the aim to address the specific needs of PWDs including the people around them, particularly the trainers, who should know how to deal with them or handle them properly, so every person's capacity to contribute in a meaningful way for the country will be recognized.

\section{Significant Difference on the Respondents' Level of Awareness on Deaf Culture and FSL Skills in the Hospitality Industry of Zamboanga City}

Table 7 shows that there was no significant difference in the respondents' levels of awareness on Deaf culture and FSL skills in the hospitality industry of Zamboanga City.

Table 7. Significant Difference Between the Respondents' Levels of Awareness on Deaf Culture and FSL Skills in the Hospitality Industry of Zamboanga City

\begin{tabular}{|c|c|c|c|c|c|}
\hline $\begin{array}{c}\text { Level of } \\
\text { Awareness }\end{array}$ & Mean & $\begin{array}{c}\text { Mean } \\
\text { Difference }\end{array}$ & t-Value & P-Value & Interpretation \\
\hline Deaf Culture & 2.68 & \multirow[b]{2}{*}{0.04} & \multirow[b]{2}{*}{-.324} & \multirow[b]{2}{*}{.753} & \multirow[b]{2}{*}{ Not Significant } \\
\hline $\begin{array}{c}\text { Sign } \\
\text { Language }\end{array}$ & 2.73 & & & & \\
\hline
\end{tabular}

Table 7 shows that the respondents' level of awareness on Deaf culture had a mean of 2.68 and the respondents' level of awareness on Filipino sign language skills had a mean of 2.73 with a mean difference of 0.04 . The mean difference of $(0.04)$ was not statistically significant with the computed t-value of -.324 and a p-value of 0.753 since the p-value was greater than the Alpha of 0.05 level of significance.

The hypothesis stated that there was no significant difference between the respondents' levels of awareness on the Deaf culture and Filipino sign language skills in the hospitality industry of Zamboanga City was accepted. It implied that there was not enough evidence showing that the level of awareness between the respondents differed from each other.

\section{Intervention Program}

This study revealed that an intervention program in relation to increasing the employability of Deaf individuals in the hospitality industry is needed; a Training-to-Employment program is ideal to be developed with a goal of boosting the morale and self-esteem of both Deaf and hearing workforce (border crossers) in the hospitality industry (borderland). In a vision of this, there will be Deaf inclusivity in the hospitality industry for both employees and guests where equality, diversity, and quality guest services may thrive. Thus, there may be an increase in the number of 
border crossers who may do the crossing of virtual borders in such borderlands (hospitality spaces).

This intervention program can be carried out by the government and private organizations and agencies through a collaboration of their services, goals, or Corporate Social Responsibility (CSR). A good benchmark for this intervention program is Marriott Manila's collaboration with the Philippine School for the Deaf whose hospitality training center was newly reconstructed Marriott's executives and staff have taken part in its refurbishing to give Deaf trainees a conducive facility for hospitality learning in Marriott's continuing efforts to be the leader in CSR. This goes to show that Marriott workforce were border crossers in borderlands and had initiated their intent to do the crossing of virtual borders towards the Deaf world as this development was said to be part of the long-term partnership of the hotel and the school in order to achieve impactful results for students with hearing disabilities; this step by Marriott was said to show how Marriott redefines hospitality - going beyond their premises and being a positive influence to its community according to Hospitality News Philippines (2013, Feb 25). Marriott, as a hospitality employer supporting the training Deaf individuals with hospitality skills, carried out acts of fostering Deaf employability in the hospitality industry and is an indication of increased chances of hospitality employment for Deaf individuals being trained for such.

In line with these, government agencies that support the welfare of Deaf individuals and the inclusivity in the hospitality environment - or the potential border crossing border crossers in borderlands under the government sector - such as the Department of Labor and Employment (DOLE), Department of Social Welfare and Development (DSWD), and particularly Technical Education Skills Development Authority (TESDA) can collaborate to come up with training and tieups with hospitality establishments not only for wok immersion purposes but also for employment allocation and hiring considerations of trained Deaf individuals - who, if not hired after being skillfully competent upon to completion of their training and work immersion may result to an undesirable added trauma to an already evident stigma in the society. Thus, the attempt to do the crossing of virtual borders will be a failure. To avoid such mistake, this intervention program must be strengthened with advocacy in the hospitality industry whereby hearing hospitality stakeholders' sensitivity to the Deaf community needs to be addressed incongruent to the statement of Berta, D. (2001) that conducting diversity training and sensitivity classes for its unit managers prepares an environment in which non-traditional workers can excel. In addition, hospitality operators considering the hiring of non-traditional workers need to prepare to create an atmosphere where the worker can excel, according to Gilbert Melott, vice president of business process and education for Benningan's restaurants in Plano, Texas as stated by Berta, D. (2001).

This step will likely increase workplace accommodation for Deaf individuals, hopefully resulting in hospitality borderlands being positively diverse in nature that may certainly reflect better quality services received by Deaf guests or provided by both Deaf and hearing hospitality workforce. To be specific, training programs must include basic Filipino Sign Language (FSL) skills aligned to the needs of the hospitality industry's activities which have forms of specific or special directions and instructions according to the demands of the work system, working conditions, and operations towards quality work precision - examples of useful operation-specific terms that can be learned by hospitality workforce (border crossers) are stated by Berta, D. (2001) that employees 
have picked up a little sign language and are able to sign such words such as French fries and tater tots.

Hence, the Deaf sensitivity program for the hearing hospitality workforce could support the increase in chances of virtual border crossing by border crossers in such borderlands. Practically, it is inevitable for employers in the hospitality industry to have hiring considerations when it comes to the hearing impaired. This is in conjunction with the statement of Amir, Strauser and Chan (2009) as cited by Burke, J., Bezyak, J., Fraser, R., Pete, J., Ditchman, N., et al. (2013, July) that there are many positive attributes and reasons for hiring PWDs. However, negative attitudes of coworkers or supervisors and the lack of supply of qualified PWDs were frequently cited as major barriers to hiring and retaining them. In Zamboanga City, the AVRC (Area Vocation Rehabilitation Center) arm of DSWD IX has sent a Deaf individual, who submitted his Deaf Profile to the present researcher on May 26, 2019 - wrote of his work immersion training at the LM Hotel effective 15 June 2019. In the process of the researcher's study, she has spread awareness to some degree, among the hospitality industry stakeholders, on the employability of Zamboangeño Deaf individuals in the local hospitality industry. This most recent development on Deaf immersion in the hospitality industry in conjunction with their skills training acquisition is a new venture or act of crossing virtual borders by border crossers, particularly the AVRC in the borderlands of Zamboanga city. This is said because there was no Deaf individual employed in any hospitality organization as a result of no hospitality training given to any Deaf student under AVRC as reflected in their Deaf employment report covering the period of January to April 2019. Given that it is a very new scheme, this particular AVRC project cannot be taken as a benchmark yet, but it can serve as a starting point for this intervention program to take flight. With substantial support from Deaf advocates and industry partners taking into consideration this proposed intervention program by the present researcher, Deaf employment in the hospitality industry may be fostered.

\section{CONCLUSION}

Based on the findings of the study, it concluded that: 1) the hospitality industry stakeholders in Zamboanga City were aware of the Deaf culture and Filipino sign language skills among the Deaf and hearing individuals despite the differences in the linguistic aspects of the sign languages such as semantics (meaning), syntax (grammar), lexicon (vocabulary), and pragmatics (expression); 2) the stakeholders in the hospitality industry were able to communicate with Deaf individuals through gestures and writing or any visual medium of communication in different borderlands despite having little or no FSL skills or knowledge on Deaf culture including the uniqueness of the Deaf grammar; 3) the communication models played a great role in the hospitality employment opportunities and capabilities of Deaf individuals; 4) awareness and understanding of Deaf culture and Filipino Sign Language in the course of interactive interaction among Deaf and hearing individuals in the business operations of the hospitality industry were very crucial in the communication patterns that occurred or may still occur.

\section{Recommendations}

This study recommends the following points so that the Deaf people in Zamboanga City will have sustainable employment in the hospitality industry: 1) Establish a specific Filipino Sign Language skill that considers the needs of both the hearing and Deaf individuals in the hospitality 
industry to facilitate their communication. 2) The specific FSL skills should be supported by teacher or trainers with tangible teaching materials that could be moderated by concerned government agencies like DOT, Technical Education Skills Development Authority (TESDA), Department of Labor and Employment (DOLE), Department of Social Welfare and Development (DSWD), Department of Education (DepEd), or Commission on Higher Education (CHED). 3) Conduct a curriculum review on Deaf culture and communication competencies for Senior High School (SHS) Technical-Vocational track. 4) Established a standardized FSL. 5) Open more job opportunities and workplace inclusivity in the hospitality industry for Deaf individuals. 6) There must be Deafcentered programs for food-related entrepreneurship. 7) Include Deaf-friendly aspects in the accreditation criteria by the Department of Tourism for hospitality establishments. 8) Put up a Deaf welfare program for Deaf individuals where they can access their psycho-social needs so that their output on hospitality quality services could be attained. 9) Parallel studies must be conducted to validate the findings of the present investigation.

\section{REFERENCES}

Arboleda, R. J. I. (2007). Acculturation and acceptance of deafness among Asian and Asian American deaf and hard of hearing people in the united states (Order No. 3275129). Available from Social Science Database. (304869757). Retrieved from https://search.proquest.com/docview/304869757?accountid=38643

ASL THAT (2016, Oct 19). ASL vs. SEE comparison | ASL - American sign language. Retrieved from https://www.youtube.com/watch?v=hvqZ83pS0B4/ June 4, 2019.

Berta, D. (2001). Amid drought operators tap new labor reservoirs. Nation's restaurant news, 35(13), 4. Retrieved from https://search.proquest.com/docview/229343860?accountid=38643

Burke, J., Bezyak, J., Fraser, R., Pete, J., Ditchman, N., et al (2013, July). Employers' attitudes towards hiring and retaining people with disabilities: a review of the literature. The Australian Journal of Rehabilitation Counseling; Sydney Vol. 19, Iss. 1: 21-38

Case, B. A. (2000). Using analogy to develop an understanding of deaf culture. Multicultural $\begin{array}{llll}\text { Education, } & 7(3), & \text { Retrieved }\end{array}$ https://search.proquest.com/docview/216505894?accountid=38643

Chuang, P. M. (2012, Mar 26). Giving a leg-up to disabled workers. The Business Times Retrieved from https://search.proquest.com/docview/940849951?accountid=38643

Coco-Ripp, J. (2003). The effect of awareness training and planned contact on the provision of an inclusive environment for persons who are deaf (Order No. 3094280). Available from Nursing \& Allied Health Database. $\quad$ (305297040). Retrieved from https://search.proquest.com/docview/305297040?accountid=38643

Dandee (@ 2009 - 2012) RR of RA 10754 - an act expanding the benefits and privileges of persons with disability (PWD). National Council on Disability Affairs Retrieved from https://www.ncda.gov.ph/disability-laws/implementing-rules-and-regulations-irr/irr-of-ra10754-an-act-expanding-the-benefits-and-privileges-of-persons-with-disability-pwd/June 17 , 2019)

Disability Info South Africa (2016). Unlocking the shackles of your disability using the key of knowledge. Retrieved from http://disabilityinfosa.co.za/hearing-impairments/hobbies/June 20, 2019, para. 1. 
Feigenbaum, P. (2017, Oct 16). Hospitality industry bridges the communication gap between hearing and Deaf. Retrieved from https://www.smartmeetings.com/news/103143/hospitalitycommunication-deaf?fbclid=IwAR2XaBrot06-

e7CTEOBCga21NcAF0VlwbXU7878LLsim2zFi7vy_iDCCT74

Gunay, A. (2018, July). Gov't frontline offices learn sign language to better aid PWDs. Retrieved from http://naga.gov.ph/news/govt-frontline-offices-learn-sign-language-to-betteraid-pwds/

Hiddinga, A., \& Crasborn, O. (2011). Signed languages and globalization. Language in Society, 40(4), 483-505. doi:http://dx.doi.org/10.1017/S0047404511000480

Himor, J.P. (2018, Oct 12). LOOK: These 7 Admirable establishments hire PWD employees. Retrieved from https://www.wheninmanila.com/look-these-7-admirable-establishments-hirepwd-employees/?fbclid=IwAR3sRlgVGAm-7l3YEcxnz-

1TMPzpVfGmXXxEbBtsZ1KcjbxF31CRxbICJwo

Hospitality News Philippines (2013, Feb 25). Service beyond disability. Retrieved from https://hospitalitynews.ph/209/service-beyonddisability/?fbclid=IwAR1IK98CsITq3XJsrIY7aqwYmn79WDIgQJeGwjp-sQzlnfwFqNuoKExH85s/ May 29, 2019.

Hospitality News Philippines (2018, Jun 5). Marriott launches hospitality training center for the deaf. Retrieved from https://hospitalitynews.ph/3976/marriott-launches-hospitality-trainingcenter-for-the-deaf/ April 3, 2019.

InfoBoholPhilippines (2018, Aug 31). Dao diamond hotel tagbilaran city, bohol, philippines. Retrieved from https://www.infobohol.com/dao-diamond-hotel-tagbilaran-city/ April 3, 2019.

Kazmin, A. (2018, Mar 16). Positive signs. Financial Times. Retrieved from https://search.proquest.com/docview/2025226645?accountid=38643

Kreher, Y.W. (2013). Crossing from hearing to deaf worlds: hearing border crossers as participatory designers in healthcare instruction. Instructional Design, Development and Evaluation - Dissertations. Paper 64. Syracuse University.

McCaskill, A., \& O'Brien, C. (2016). Outsiders in a hearing world: a book still relevant today. American Annals of the Deaf, 160(5), 510-513. doi:http://dx.doi.org/10.1353/aad.2016.0004. Retrieved from https://www.researchgate.net

Modern Signs Press (C) 1973-2019). Signing exact English. Retrieved from https://www.signingexactenglish.com/?pageid=2/June 17, 2019.

Nordqvist, C. (2018, Jun 27). What's to know about deafness and hearing loss? Retrieved from https://www.medicalnewstoday.com/articles/249285.php/ May 7, 2019.

O'Grady, C. (2018, Nov 01). First signing Starbucks store opens in D.C. University Wire Retrieved from https://search.proquest.com/docview/2127535346/E00F96CEC54648E8PQ/3?accountid=3864 3/ May 18, 2019.

Palmer, D. (2019, Apr 19) Building a more inclusive workplace for people with disability. The CEO Magazine Retrieved from https://www.theceomagazine.com/business/healthwellbeing/building-a-more-inclusive-workplace-for-people-with disability/?fbclid=IwAR0rremgWMHpTosZM-rqUy1XZFgBQ8Fx25uL3oXRsMCeWYKRWbkBuB4_xc/ April 30, 2019. 
Patigayon, L., S.N. (2018). A little bit of sign goes A long way (4) deaf culture awareness in nursing practice. Nevada information, 27(1), 14. Retrieved from https://search.proquest.com/docview/1989175498?accountid=38643

Peters, S. W. (2007). Cultural awareness: Enhancing counselor understanding, sensitivity, and effectiveness with clients who are deaf. Journal of Multicultural Counseling and Development, 35(3), 182-190. Retrieved from https://search.proquest.com/docview/235997872?accountid=38643

Saqueton, G. \& Uychoco, M. (2016). English for academic and professional purposes. Rex Bookstore Inc. SKU: 09-AA-00002-0

Senghas, R. J., \& Monaghan, L. (2002). Signs of their times: Deaf communities and the culture of language. Annual Review of Anthropology, 31, 69-97. doi:http://dx.doi.org/10.1146/annurev.anthro.31.020402.101302

Stokar, H. (2017). Deaf workers in restaurant, retail, and hospitality sector employment: harnessing research to promote advocacy. Journal of Social Work in Disability \& Rehabilitation, 16:3-4, 204-215. Retrieved from https://www.tandfonline.com/doi/full/10.1080/1536710X.2017.1372237

TESDA assures best care for PWDs (2015, Jun 7). Retrieved from https://www.tesda.gov.ph/News/Details/6502?fbclid=IwAR2AKYWJG3kDQWF8HZGyyWTOE8_1 V11q-zRnIbYsog6D4AJtF_AiIQHFW2M/ May 18, 2019.

Zahari, M. et al. (2010). Employment opportunities of the hearing impaired in the hospitality industry: gender analysis. World Appl. Sci. J., 10 (Special Issue of Tourism \& Hospitality): 126135, 2010, ISSN 1818-4952 